\section{Epilogue: Is the State Back in}

\section{Fashion?}

\section{Mick Moore}

IDS Bulletin Vol 29 No 21998
The Economist does not panic easily. When it shows signs of alarm, something significant is probably happening. The cover page of the 20th September 1997 issue bears the warning 'Big government is still in charge'. The lead article and a 24-page survey 'The world economy' explain that, contrary to almost universal belief, the revolution against the state has failed. Despite Thatcherism, Reaganism, monetarism, neo-liberalism, privatisation, deregulation, globalisation, falling tax rates and 'the cuts' (in public expenditure), the state in the rich industrial countries continues to grow, to absorb a steadily increasing proportion of GNP, and to pose an increasing threat to liberty. The current orthodoxy is that the market has triumphed over the state; 'Indeed, the worry that one hears again and again is that "the pendulum has swung too far", and needs to be pushed back somewhat in the direction of a larger, or anyway shrewder, role for government (p.17)' Yet, says The Economist, almost everyone is wrong. Unless something really radical is done, the state will continue to inflate, and liberty and capitalism to shrink and shrivel.

Fortunately for the anti-state rebels, The Economist is wrong. Its analysis is seriously at fault in at least three respects:

First, the notion that smaller government automatically implies more liberty is absurd. Try telling that to Russian citizens who have little protection for their persons or their rights because their government cannot raise the revenue to pay its police, judicial or penal services - or to undertake any of the dozens of other governmental tasks that, when performed properly, provide the basis for human rights and civil liberties. ${ }^{1}$

Second, it is naive of The Economist to suggest that the power of states can usefully be measured by the ratio of government spending to GNP. Size does not indicate power, any more than the influence of politicians can be measured by their girth. States have become weaker in relation to markets and capital over recent decades because globalisation, reduced capital controls and cheaper communications and transport offer the managers of

\footnotetext{
1 The linkage between weak states and the denial of freedom in contemporary Russia is eloquently explored by Holmes (1997).
} 
capital more choices and more bargaining power in relation to governments. Big transnational corporations, small companies and money managers all enjoy much more discretion about whether to move their 'hot money' from Kuala Lumpur to Madrid, whether to construct their new assembly plant in Recife or Kiev, and whether to have their data processing done in Bangalore or Wexford rather than 'at home' in Frankfurt (Cohen 1996; Winters 1996: Chapter 1). Capital has used this enhanced bargaining power to lower its tax liabilities. The Economist itself ('Survey of the world economy', p.30 - see also Rodrik 1997) concedes the most striking evidence: the governments of the OECD countries increasingly depend for their finances on taxing the incomes of labour, while lowering the tax burden on profits and other income from capital.

Third, as The Economist also concedes, the continuing growth of government spending that is the focus of its dismay is propelled in large part by forces considerably less sinister than the inherent expansionist tendencies of the demonic state. The dominant cause is demographic. The populations of the rich countries are ageing rapidly. They still depend mainly on the state for their pensions, and those pensions are still funded mainly through current taxation ('Survey of the world economy', pp.8 and 46). The anti-state revolutionaries have not been comprehensively cheated. They have simply been unwilling or unable to force OECD governments to renege massively on their obligations to growing masses of grey-haired citizens.

The Economist is certainly being unduly alarmist from a factual perspective: the anti-state revolution has had a real impact. From the tactical perspective of a committed anti-statist ideologue, these alarms make sense. The anti-statists are losing ideological ground. The Economist is correct in detecting a widespread sense that the famous pendulum had indeed swung too far against the state, and that some swing back is justified. The publication of WDR97 itself constitutes part of the swing back. The swing is likely to continue because it appears to be embedded in a recent shift in the one opinion that counts above all others in shaping global ideological fashions - that of the United States public. For over three decades, the American public have been regularly surveyed to assess their gut views about government. In 1965, three-quarters said that they had great confidence in their federal government. By 1985 this figure had declined to a mere 15 per cent - both a cause and a consequence of the rise of anti-state political sentiment in the US and in the international financial institutions that nestle in Washington D.C. under the eyes of the US Congress. Yet in a mere two years, by 1997, this figure has fairly shot up to 22 per cent, with equivalent increases in the figures for state and local government (The Boston Globe, 12 October 1997).

We do not know exactly why the state is being viewed with more sympathy recently, but can make some good guesses. The consequences of the crumbling or complete breakdown of order in much of the former Soviet Union and in some parts of Africa (in particular) have drawn attention to some of the positive aspects of governments. Criminal mafias, ethnic warriors and unpaid police forces can be as oppressive and cruel as the agencies of authoritarian states (Holmes 1997). Increasingly-global economic, financial and environmental crises - the Mexico peso crisis of 1994; the economic and financial turmoil in Asia in 1997; the rapid recurrence of the El Nino phenomenon; Indonesia's recent forest fires - have reminded world opinion of the risks of global 'laisser faire'. It is just possible that the increasing volume of evidence about the growth of economic inequality in the rich countries is also having some influence.

These ideological battles are fought in highly metaphorical terms. We take metaphors like the state, 'the market' and 'civil society' and then make gross assertions about the nature of the relationship between them. For the anti-state revolutionaries, the state and the market simply crowd out one another while, by some leap of logic that defies explanation, the market and civil society are mutually reinforcing. This procedure appears to justify some very simple statements e.g. 'More government always equals less liberty' (Jeff Jacoby in The Boston Globe, 12 October 1997). Conservatives (of various stripes) instead use the metaphor of inter-dependence: markets need governments to function effectively (Andrea Cornia in this Bulletin); so too does civil society (Evans 1997). We are not likely to proceed very far in understanding the world if we continue to cast these inflated metaphors at one another. But we do need to have our metaphors available for self-defence in 
the event that the other side launch theirs. WDR97 validates the continuing use of both sets, and thereby provides some cover for those researchers and practitioners who see their mission as learning how to multiply the virtues of governments.

\section{References}

Cohen, B., 1996, 'Phoenix risen: the resurrection of global finance', World Politics, Vol 48 No 2 : 268-96.

Evans, P. (ed.), 1997, State-Society Synergy: Government and Social Capital in Development, Berkeley: University of California, International and Area Studies.

Holmes, S., 1997, 'What Russia teaches us now: how weak states threaten freedom', The American Prospect, Vol 33 No July-August: 30-9.

Rodrik, D. (ed.), 1997, Has Globalization Gone Too Far?, Washington D. C.: Institute for International Economics.

Winters, J. A., 1996, Power in Motion: Capital and the Indonesian State, Ithaca and London: Cornell University Press. 


\section{REVIEW BOOKS RECEIVED}

Henry J. Bruton, On the Search for Well-Being, The University of Michigan Press, 1997.

Peter Colley, Reforming Energy: Sustainable Futures and Global Labour, London and Chicago, IL: Pluto Press, 1997.

Aidan Cox, John Healey and Antonique Koning, 'How European aid works: a comparison of management systems and effectiveness', ODI Research Study, ODI, 1997.

Jean Drèze and Amartya Sen (eds), Indian Development: Selected Regional Perspectives, Oxford University Press, 1997.

Ahmed Galal and Bernard Hoekman (eds), Regional Partners in Global Markets: Limits and Possibilities of the Euro-Med Agreements, CEPR/ECES, 1997.

Martin Godfrey (ed.), Skill Development for International Competitiveness, Edward Elgar, 1997.

Jan P. de Groot and Ruerd Ruben (eds), Sustainable Agriculture in Central America, Macmillan Press, 1997.

Rachel Hastie, Disabled Children in a Society at War: A Case Book from Bosnia, Oxfam, 1997.

Homa Hoodfar, Between Marriage and the Market: Intimate Politics and Survival in Cairo, Berkeley, Los Angeles and London: University of California Press, 1997.

Michael O'Hanlon and Carol Graham, A Half Penny on the Federal Dollar: The Future of Development Aid, Brookings Institution Press, Washington, D.C., 1997.

Michael Richards, 'Missing a moving target? Colonist technology development on the Amazon frontier', ODI Research Study, ODI, 1997.

Amartya Sen (with James Foster), On Economic Inequality, Expanded Edition, Clarendon Press, 1997.

Rachel Slocum, Lori Wichhart, Dianne Rocheleau and Barbara Thomas-Slayter (eds), Power, Process and Participation: Tools for Change, Intermediate Technology Publications, 1995.

Peter Strachan with Chris Peters, Empowering Communities: A Case Book from West Sudan, Oxfam, 1997.
David Tolfree, Restoring Playfulness: Different Approaches to Assisting Children who are Psychologically Affected by War or Displacement, Rädda Barnen, 1996.

William Tordoff, Government and Politics in Africa, Third Edition, Macmillan Press, 1997.

Aili Mari Tripp, Changing the Rules: The Politics of Liberalization and the Urban Informal Economy in Tanzania, Berkeley, Los Angeles and London: University of California Press, 1997.

Mark Turner and David Hulme, Governance, Administration and Development: Making the State Work, Basingstoke and London: Macmillan Press, 1997.

Centre for Advanced Training in Agricultural and Rural Development, Qualitative Impact Monitoring of Agricultural Structural Adjustment in Jordan, Humboldt University Berlin, 1996.

Creditor Reporting System Gazette, Quarterly report on individual aid commitments: December 1996 to February 1997, OECD, 1997.

Development in Practice Reader: Development for Health, Oxfam (UK and Ireland), 1997.

Richard Grabowski and Michael Shields, Development Economics, Blackwell, 1996

Yujiro Hayami, Development Economics: From the Poverty to the Wealth of Nations, Clarendon Press, 1997.

James Sumberg and Christine Okali, Farmers' Experiments: Creating Local Knowledge, Lynne Rienner Publishers, 1997.

Osama J.A.R. Abu Shair, Privatization and Development, Macmillan, 1997

James M. Cypher and James L. Dietz, The Process of Economic Development, Routledge, 1997.

Caroline Sweetman (ed.), Gender in Development Organisations, Oxfam, 1997.

István P. Szekely and Richard Sabot (eds), Development Strategy and Management of the Market Economy, Vol II, Clarendon Press, 1997.

World Bank, 'The state in a changing world', World Development Report, 1997, Oxford University Press, 1997. 